\begin{tabular}{|l|l|l|l|l|}
\hline Journal of Coastal Research & SI & 92 & $157-164$ & Coconut Creek, Florida \\
\hline
\end{tabular}

\title{
The Role of Coral Reefs in Coastal Protection: Analysis of Beach Morphology
}

\author{
Karoline Angélica Martins ${ }^{\dagger *}$, Pedro de Souza Pereira ${ }^{\dagger \dagger}$, Luciana S. Esteves ${ }^{\ddagger}$, and Jon Williams ${ }^{\ddagger \ddagger}$ \\ ${ }^{\dagger}$ Laboratory of Geological \\ Oceanography \\ Oceanography Department \\ Universidade Federal de \\ Pernambuco \\ Recife, Pernambuco, Brazil \\ tDepartment of Life \& \\ Environmental Sciences \\ Faculty of Science and \\ Technology \\ Bournemouth University \\ Horts, Coastal \& \\ Offshore \\ Mott MacDonald \\ Croydon, London, UK
}

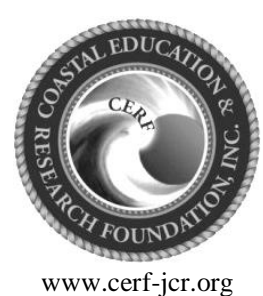

www.cerf-jcr.org

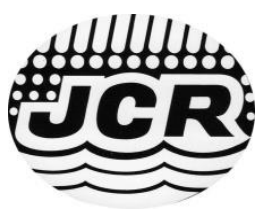

www.JCRonline.org

\begin{abstract}
Martins, K.A.; Pereira, P.S.; Esteves, L.S., and Williams, J., 2019. The role of coral reefs in coastal protection: Analysis of beach morphology. In: Silva, R.; Martínez, M.L.; Chávez, V., and Lithgow, D. (eds.), Integrating Biophysical Components in Coastal Engineering Practices. Journal of Coastal Research, Special Issue No. 92, pp. 157-164. Coconut Creek (Florida), ISSN 0749-0208.

This paper evaluates the effect of a fringing reef on the morphodynamic behaviour of adjacent beaches in terms of profile stability and cross-shore sediment exchange. Variations in subaerial beach morphology along 39 crossshore profiles at Pontal do Cupe beach (Northeastern Brazil) were analysed, using modelled wave data and monthly beach topography acquired from November 2014 to September 2016. Pontal do Cupe has a reef to the south but is exposed to waves in the north, making this an ideal location to assess the sheltering effect of the reef. Beach volume and beach width data were used to compare the reef-fronted profiles with those of the exposed adjacent beach. Seven groups of profiles were identified by applying Principal Component Analysis to the topography dataset. A simple numerical model was used to quantify the role of the reef in dissipating wave energy, showing a reduction of approximately 50\% in incoming wave energy to the shore. The reef-fronted beach is significantly more stable than the exposed beach. Total beach volume is similar for both the exposed and the reef-fronted beach. The results of this survey can be used as a proxy for the ecosystem service of coastal protection provided by reefs.
\end{abstract}

ADDITIONAL INDEX WORDS: Beach profile, principal components analysis - PCA, beach stability, wave energy, Brazilian Northeast.

\section{INTRODUCTION}

Coral reefs provide ecosystem services that are fundamental to human well-being (Albert et al., 2015), including coastal protection, maintenance of species biodiversity, provision of food, recreation and aesthetic value (Moberg and Folke, 1999). It is estimated that reefs are responsible for preventing more than $\$ 4$ billion in damages from storms per year (Beck et al., 2018). Such damage is avoided through water wave energy attenuation, which creates a sheltering effect facilitating sediment accumulation and beach stability. By altering the physical environment, corals can contribute to the development of other ecosystems such as seagrass beds and mangroves (Barbier et al., 2011). Wave transformation across reefs is the main driver of the ecosystem protection service, as previously observed elsewhere (Van Zanten, Van Beukering, and Wagtendonk, 2014). Up to 97\% of wave energy can be dissipated by reefs (Ferrario et al., 2014), with wave height decreasing by $25-55 \%$ depending on the depth and extension of the reef (Costa et al., 2016).

DOI: 10.2112/SI92-018.1 received 1 December 2018; accepted in revision 20 January 2019.

*Corresponding author: karol.martins@ msn.com

${ }^{\circ}$ Coastal Education and Research Foundation, Inc. 2019
Generally, reef-fronted beaches have a steep reflective upper beach and a featureless intertidal area (Short, 2006). Reef-fronted beaches are considerably less dynamic than beaches without a reef (Alegria-Arzaburu et al., 2013; Gallop et al., 2011). For the same offshore wave conditions, exposed beaches usually exhibit wide morphological complexity, whereas reef-fronted beaches usually have fewer three-dimensional features (Alegria-Arzaburu et al., 2013; Mallmann et al., 2014).

This study aims to assess the coastal protection ecosystem service provided by the Cupe reef by comparing the temporal and spatial variability of beach profiles in the lee of the reef and at the adjacent, exposed shoreline. The beach configuration found at Pontal do Cupe beach is similar to several other reef-fronted beaches in Brazil, therefore it is a reference to understand the effects of coral reefs on beach morphology for the region.

\section{Study Site}

Pontal do Cupe beach is located to the south of Recife, the capital of Pernambuco state, in the northeast of Brazil. It can be characterized as a reflective beach, dominated by carbonate medium sand, with morphology influenced by the reef lying parallel to the shore (Dominguez et al., 1990). The reef is formed by corals, calcareous algae and molluscs (Ferreira and Maida, 2006). At low tide, especially during spring tide, the reef flat of 
Pontal do Cupe beach is exposed, confining water masses that form pools and natural channels (Figure 1).

The region has a tropical Atlantic climate, with an annual average temperature of $24{ }^{\circ} \mathrm{C}$ and annual precipitation of about 2,000 mm, mainly in March to September. Southeast trade winds prevail in the study area and determine the wave climate. Waves from ESE with a mean height of $1.7 \mathrm{~m}$ and peak period of $8.9 \mathrm{~s}$ dominate throughout the year. The dominant ESE waves determine the sediment transport by longshore drift to the north (Pereira et al., 2015). According to tide data provided by the Brazilian Directory of Hydrography and Navigation, the semidiurnal tidal range in the region is mesotidal. Nearby reeffronted beaches have a slightly concave morphology with variable slopes, depending on sediment grain size and incident wave climate (Mallmann et al., 2014)

\section{METHODS}

Variability in beach topography and wave energy dissipation are used in this paper as proxies to analyze the coastal protection provided by the reef at Cupe. The assessment of beach behavior according to wave changes was based on two years of monthly beach topography data and offshore wave data from the model Wave Watch III (WWIII) (Tolman, 2009).

\section{Fieldwork}

Beach topography data were obtained from 39 cross-shore profiles, spaced every $60 \mathrm{~m}$. Monthly beach profiles were measured from November 2014 to September 2016 at low spring tides, to enable data collection, extending from the dune toe, vegetation line or seawall to approximately $1 \mathrm{~m}$ below mean water level, covering the entire low tide terrace.

The survey was performed using a pair of R3 and R4 Trimble Kinematic GNSS (Global Navigation Satellite System) recording at 5-second intervals, using the official Brazilian datum SIRGAS 2000, and the vertical Imbituba datum. The base was positioned at the IBGE (Brazilian Institute of Geography and Statistics) geodetic station number 93804. Following postprocessing, terrain latitude, longitude and elevation were obtained with a precision of $1 \mathrm{~cm}$.

A detailed bathymetric survey of the reef zone was conducted using a single-beam $200 \mathrm{kHz}$ echo-sounder (Garmin 298 with a GPS antenna for navigation and positioning), sampling at $0.5 \mathrm{~Hz}$. A total of 40 cross-shore profiles, spaced every $100 \mathrm{~m}$ alongshore and extending were measured from the shoreline to the $20 \mathrm{~m}$ isobath. One of the bathymetric transects showing changes in elevation across the reef was used in numerical modelling.

\section{Numerical Modelling}

XBeach is a model for wave propagation, long waves and average flow, sediment transport and morphological changes in the nearshore area, beaches, dunes and back-barrier during storms (Roelvink et al., 2010). The 1D Xbeach non-hydrostatic wave model was used in a simple simulation to assess the role of the reef in dissipating wave energy. A selected set of forcing conditions was first applied to simulate wave propagation across the reef for one of the measured bathymetric transects and the resulting beach morphology over two tidal cycles ( 25 hours). The bathymetry of the study area showed two main submerged reef patches and an occasionally emerged coastal reef (Figure 2).

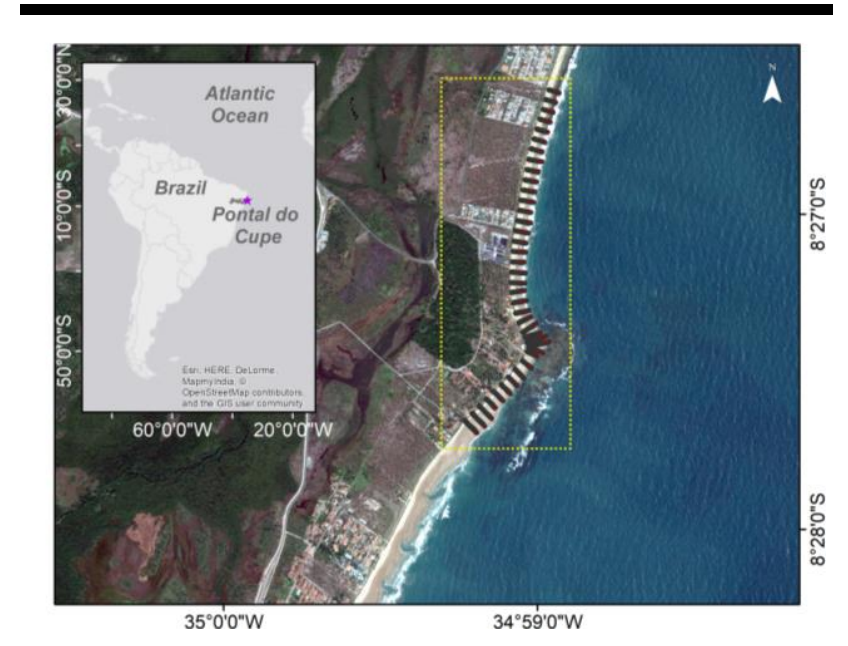

Figure 1. Location of Pontal do Cupe beach. The satellite image (Google Earth 2010) shows the reef flat exposed at low tide. The lines on the beach show the position of beach profile measurements.

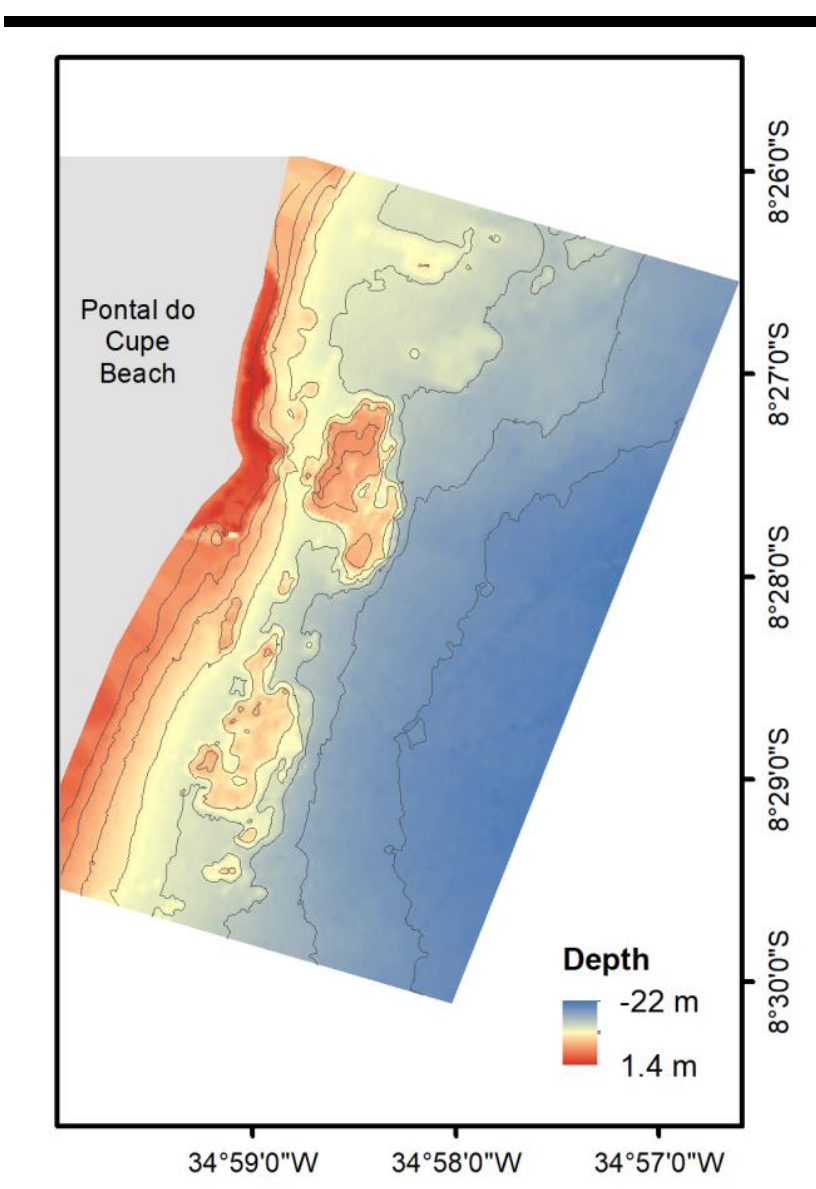

Figure 2. Local bathymetry of Pontal do Cupe beach. 
The same conditions were then applied to simulate wave propagation in the absence of the reef. To remove the influence of other factors, all conditions were kept the same, except that the bathymetric profile had the reef artificially 'removed' (Figure 3) in the simulation. Wave parameters, such as significant wave height $\left(H_{s}\right)$, were extracted at 17 points across the profile (Figure 3 ) in both simulations.

The forcing conditions were: water levels reflecting a mean spring tide with $\mathrm{MHWL}=2.4 \mathrm{~m}$; offshore random wave conditions conforming to a JONSWAP spectrum with $H_{s}=3.0 \mathrm{~m}$ and $T_{p}=$ $8.0 \mathrm{~s} ; 5 \mathrm{~m} / \mathrm{s}$ onshore wind across the model; sediment grain size defined by $D_{50}=0.0010 \mathrm{~m}$ and $D_{90}=0.0012 \mathrm{~m}$ for the entire profile, reflecting the local sediment characteristics. The drag coefficient of reefs was the same applied to smooth concrete structures. As we do not have in situ measurements for this parameter, this assumption could lead to underestimated results. Nevertheless, since the model was applied to show the trending pattern of waves over the reefs, it does not require precise values. The model was run for 25 hours, covering two full tidal periods. Transformations regarding wave height and period were measured.

XBeach results were used to calculate changes in wave energy along the profile, particularly across the nearshore and reaching the shoreline in each scenario. The sum of wave potential and kinetic energy per unit crest can be represented by the energy equation using the significant wave height (USACE, 2008), as follows:

$$
E=\frac{\rho g}{8} H_{S}^{2}
$$

where, $E$ is the wave energy per unit of wave-crest $\left(\mathrm{J} / \mathrm{m}^{2}\right), \rho$ is the water density $\left(\mathrm{kg} / \mathrm{m}^{3}\right), g$ is the gravitational acceleration $\left(\mathrm{m} / \mathrm{s}^{2}\right)$ and $H_{s}$ the significant wave height (m). $E$ is the sum of kinetic and potential energy per unit of horizontal area. In north-eastern of Brazil, the average surface water salinity is 36 (Araujo et al., 2011) and the mean temperature is $26^{\circ} \mathrm{C}$ (Mehta et al., 1995), leading to a water density of approximately $1023 \mathrm{~kg} / \mathrm{m}^{3}$.

\section{Beach Profiles}

Temporal variations in beach elevation, morphology and volume changes can be assessed by comparing profiles taken along the same line at different times. Spatial variations can also be assessed by comparing data collected on the same date, at a series of adjacent profiles (Cooper, Leggett, and Lowe, 2000).

Principal Component Analysis (PCA) was applied to group similar beach morphology data aiming to simplify the comparative analysis and identify the most representative features. To compress the size of the dataset, the PCA computes new variables called principal components which are linear combinations of the original variables, already applied to spatial analysis of beach morphology (Lemke and Miller, 2017; Short and Trembanis, 2004). The eigenvalue associated to a variable represents its contribution to the results (Abdi and Williams, 2010).

In this paper, the mean tidal range values used as a reference for the analysis are: mean low water level $(M L W L)=0.3 \mathrm{~m}$; mean water level $(\mathrm{MWL})=1.6 \mathrm{~m}$; and mean high water level $(\mathrm{MHWL})$ $=2.4 \mathrm{~m}$ (Brazilian vertical datum - Imbituba).
For each group, the mean profile equation was defined for every survey. Using the mean equations, the beach volumes above MLWL, MWL and MHWL were calculated considering a standardized 1-m-wide profile. Beach width at each of the three water levels was also extracted (Figure 4). A relative standard deviation was used to provide for data variance in each sample.

\section{Wave Conditions}

WAVEWATCH III (WWIII) spectral model is a global wave model based on the energy conservation equation in terms of wavenumber and direction (Tolman 2009). Wave conditions were acquired from October 2014 to October 2016 on Pernambuco's continental shelf, using WWIII through the ERDDAP (available at http://oos.soest.hawaii.edu/erddap) data server (Rascle and Ardhuin, 2013).

WWIII provides detailed descriptions of wave conditions, but its accuracy is strongly dependent on the input of wind fields. A validation of WWIII $\mathrm{H}_{\mathrm{s}}$ against oceanographic buoy records, obtained at $200 \mathrm{~m}$ depth on Pernambuco's continental shelf, showed significant correlation $(\mathrm{r}=0.86)$ and a standard deviation around $0.2 \mathrm{~m}$ (Pereira et al., 2015), which is considered satisfactory for the purpose of this paper.

Wave energy was calculated every hour for the month preceding the beach profile measurement. The mean of the upper quartile (the highest $25 \%$ of the values) for each period (or the period of highest energy) was calculated to allow for a comparison between the temporal variations of mean energy across surveys.

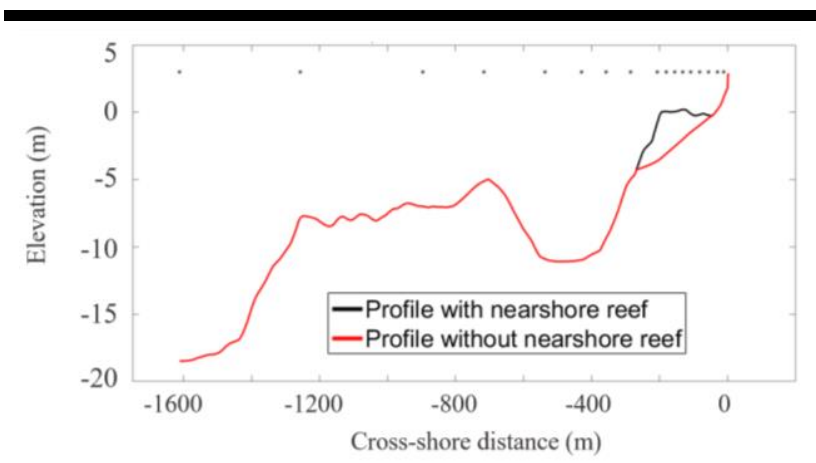

Figure 3. Bathymetric profiles used in XBeach, where the black line represents the reef-fronted beach and the red line a reef less beach; the dots indicate the cross-shore positions of data extraction.

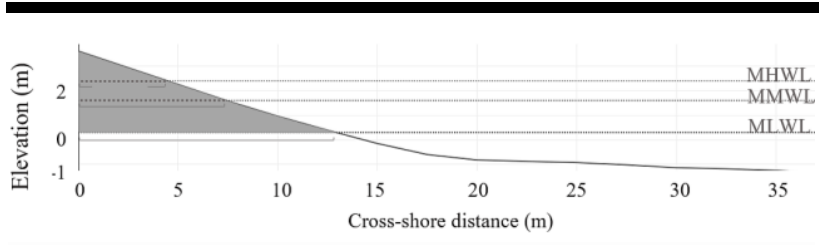

Figure 4. Beach profile sketch widths and volumes related to the three water levels (indicated by the shaded area). 


\section{Wave Dissipation over Reefs}

The model results indicate that wave heights decrease when propagating over the reefs of Pontal do Cupe (Figure 5). Therefore, they are likely to contribute to effective coastal protection.

Cross-shore changes in maximum wave height with and without the nearshore reef are shown in Figure 6. The results show attenuation in wave heights at the nearshore reef. At a 30$\mathrm{m}$ distance from the shore, the chainage marking the end of the reef, differences of up to $1 \mathrm{~m}$ in $H_{s}$ were detected between the simulations with and without the nearshore reef. Without the nearshore reef, wave height continuously increases until it breaks at the terrace, while in the profile with the nearshore reef wave height continuously decreases until it reaches the beach face (Figure 6).

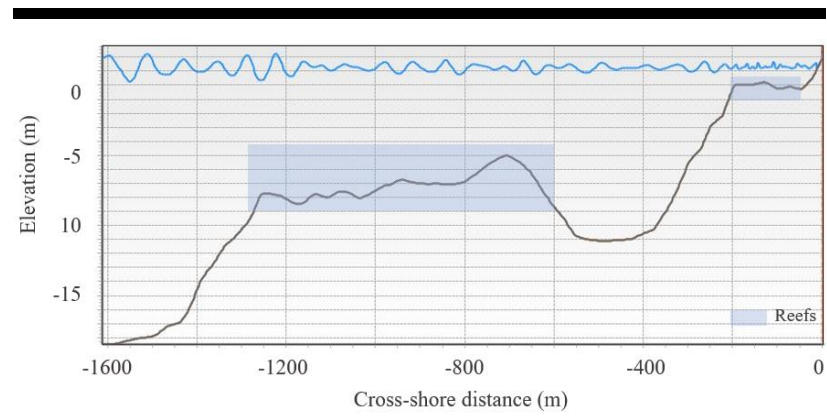

Figure 5. Bathymetric profile used as input in XBeach, with nearshore reef, and an example of the instantaneous water level result.

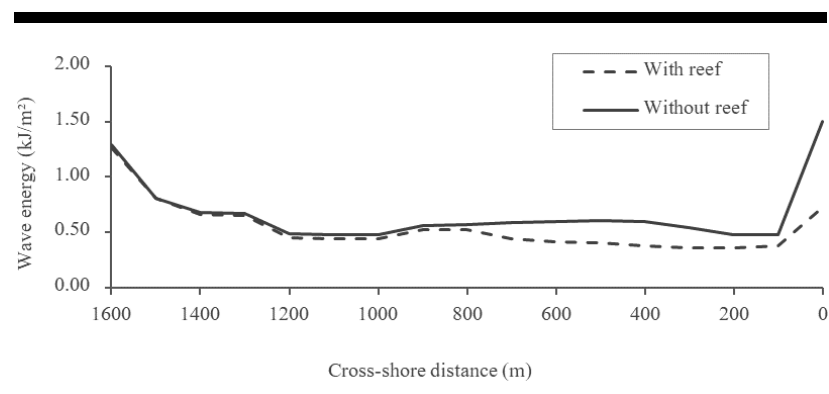

Figure 6. Wave conditions without the nearshore reef (continuous line) and with the nearshore reef (dashed line), showing the maximum wave height elevation along the cross-shore transect.

Table 1. First four principal components and percentage of variance explained.

\begin{tabular}{cccc}
\hline \hline PC & Eigenvalue & \% Total & Cumulative \\
\hline 1 & 64.8 & 47.3 & 47.3 \\
2 & 22.2 & 16.2 & 63.5 \\
3 & 8.9 & 6.5 & 70.0 \\
4 & 6.6 & 4.8 & 74.8 \\
\hline
\end{tabular}

\section{RESULTS}

Mean wave energy was calculated based on the highest quartile (25\%) extracted from the model outputs. The mean modelled wave energy reaching the coast in simulations without the reef was $1.50 \mathrm{k} \mathrm{J} / \mathrm{m}^{2}$ (SD 0.13), while in the actual bathymetry, with the reef, it was $0.72 \mathrm{~kJ} / \mathrm{m}^{2}$ (SD 0.14). Therefore, the reef contributed to a $52 \%$ reduction in incoming wave energy.

\section{Profiles Description}

Applying PCA, it was possible to identify seven mean clusters at Pontal do Cupe beach. These clusters were defined based on the variable's distances in each combination of the top four PCs, which explain $75 \%$ of the variability between the profiles (Table 1). The same statistical analysis was tested with two datasets representing summer and winter. Nevertheless, results were quite similar to the one found for the entire dataset. Therefore, the profile groups were defined based on the full period.

The first PC explains the variation in the first $20 \mathrm{~m}$ and between $70-80 \mathrm{~m}$ chainage. The second PC explains profile variation between $15-25 \mathrm{~m}$ (approximately reflecting the mean tidal level) and $60-70 \mathrm{~m}$. The third PC explains mainly the variation between the $25-45 \mathrm{~m}$ chainage. The four PCs evaluated cover most of the beach width (around $90 \mathrm{~m}$ ).

The seven profile groups defined through PCA are mapped in Figure 7 along with beach profiles representing the morphology groups. Profiles in groups 1 and 2 are relatively free from reef influence and are exposed to the incident wave climate. Wave diffraction around the reef affects profiles in groups 3 and 4, with groups 5, 6 and 7 located in the lee of the reef. In profile groups 5,6 and 7, the shoreline is fixed by construction close to the shore, preventing the natural development of beach profiles. In the latter groups, there is no dry beach (and volume above MHWL is low) during high spring tide as the waterline reaches the constructions (Figure 7).

Group 1: In group 1, beach morphology behavior is controlled primarily by the incident waves and secondly by the tide. The profiles present two key features, an upper berm with a steep beach face followed by a low tide terrace, resulting in higher volume in the upper beach (Table 2). In this area, waves approach the coast with a small angle that generates a northward longshore current.

Group 2: Beach response is mainly regulated by waves with some tidal influence reflected in the presence of a low tide terrace in some profiles. Rip currents, cusps and mega-cusps can be present (Mallmann et al., 2014). The morphology below the LWL is less steep than in Group 1, affecting volume distribution across compartments (which can be quite variable between profiles, even though the total volume is similar). Sediment volume tends to be higher at the upper beach.

Groups 3 and 4: Wave diffraction around the reef and tides influence beach morphology. Although the morphology of profiles in groups 3 and 4 are similar, the mean beach elevation in Group 3 is higher than in Group 4. Both groups show a steep and narrow high tide terrace and a gentle and wide intertidal profile, similar to the morphology observed in other beaches on the coast of Pernambuco (Pereira, Araujo, and Vaz Manso, 2016). Sediment volume is higher at the upper beach, as in Group 2. 
Group 5: The morphology of these beach profiles is primarily controlled by the tide and secondly by wave diffraction around the reef. The beach face is wider, and the low tide terrace is less marked than in the other groups. Profile morphology below the LWL is less steep and beach elevation is lower than in other groups. As a result, the profile volume is larger at the lower and intermediate beach.

Groups 6 and 7: These beach profiles are located at the lee of the reef, where wave energy dissipation is more pronounced and beach morphology is influenced mainly by tides. Although these two groups show similar beach morphology, the MLWL slope in Group 6 is less steep than in Group 7. The beach profiles have a gentle slope, with no three-dimensional features; this is the only sector where beach cusps are absent. Construction is present at the upper beach; therefore, there is no sediment volume stored in this beach compartment.

Beach width results were consistent with the beach volume pattern; therefore, the discussion is based only on beach volume.
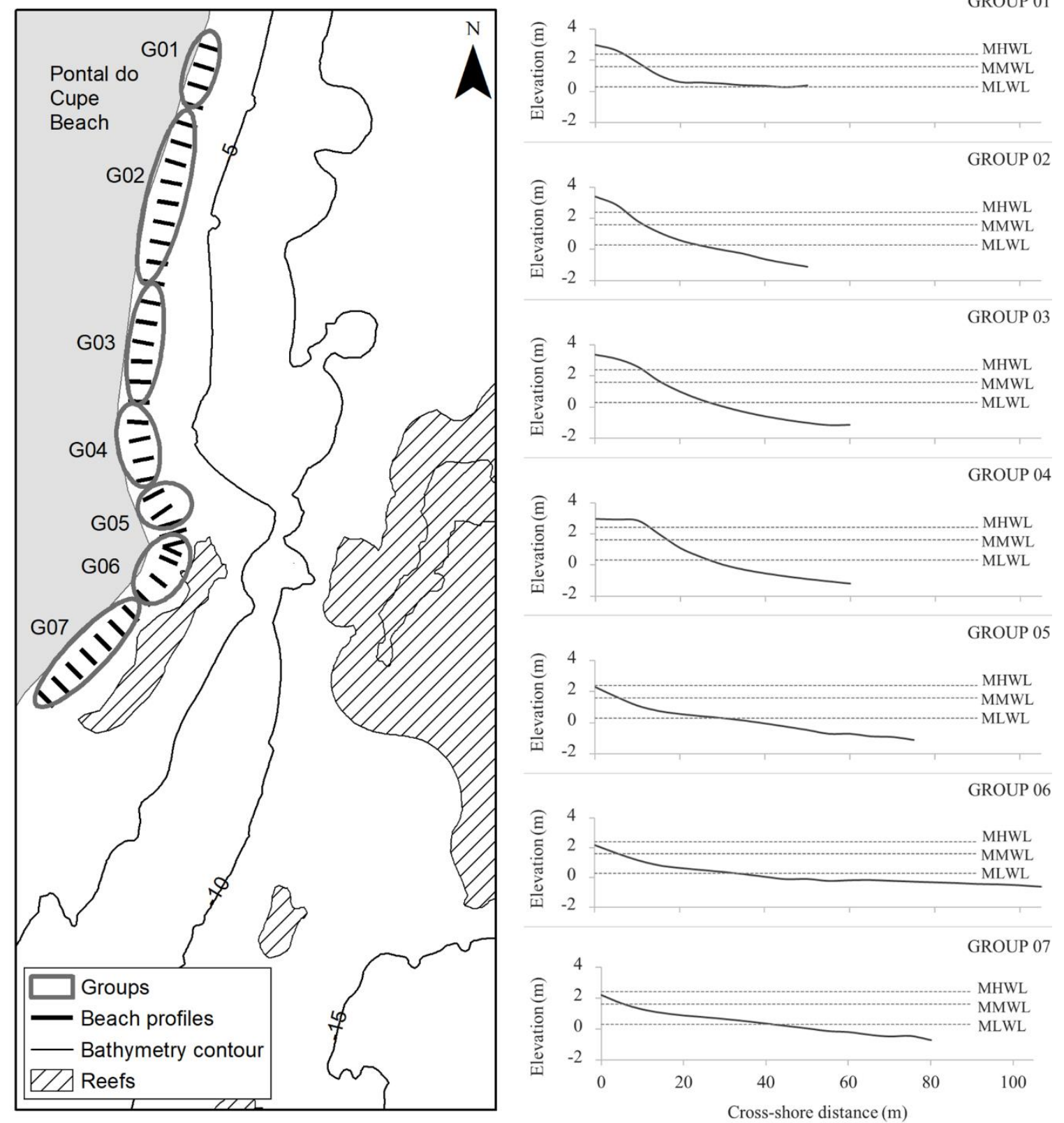

Figure 7. Groups of profiles from PCA analysis. The left figure shows the location of the profile groups; the right figure shows a representative measurement of the morphology group. 
Table 2. First four principal components and percentage of variance explained.

\begin{tabular}{lccc}
\hline \hline Group & $\begin{array}{c}\text { Vol. Lower } \\
\text { Beach }\left(\mathrm{m}^{3}\right)\end{array}$ & $\begin{array}{c}\text { Vol. Intermediate } \\
\left(\mathrm{m}^{3}\right)\end{array}$ & $\begin{array}{c}\text { Vol. Upper } \\
\text { Beach }\left(\mathrm{m}^{3}\right)\end{array}$ \\
& & & \\
\hline G01 & 23.3 & 12.1 & 12.1 \\
G02 & 12.4 & 11.7 & 19.9 \\
G03 & 11.9 & 10.9 & 30.2 \\
G04 & 12.4 & 9.1 & 25.4 \\
G05 & 19.5 & 17.7 & 4.5 \\
G06 & 24.9 & 7.9 & 0.0 \\
G07 & 22.9 & 12.3 & 0.0 \\
\hline
\end{tabular}

Table 3. Beach profile volumes of an exposed and a protected beach in a high wave energy period.

\begin{tabular}{ccc}
\hline \hline Date & $\begin{array}{c}\text { Exposed Beach Volume } \\
\left(\mathrm{m}^{3}\right)\end{array}$ & $\begin{array}{c}\text { Protected Beach Volume } \\
\left(\mathrm{m}^{3}\right)\end{array}$ \\
\hline Jun 2015 & 45.8 & 38.8 \\
Jul 2015 & 21.0 & 34.2 \\
Aug 2015 & 37.7 & 25.9 \\
Sep 2015 & 48.8 & 18.4 \\
Oct 2015 & 64.4 & 34.0 \\
\hline
\end{tabular}

\section{Temporal Variability}

The analysis of temporal variability was based on the mean profile of each group calculated for each survey date. According to the relative standard deviation of beach volumes for the time series, Groups 3 and 4 (influenced by wave diffraction) and 5 and 6 (protected by the reef) had lower standard deviation results; Groups 1, 2 and 3 (exposed) had intermediate variation, while Group 4, the most strongly influenced by wave diffraction, had the highest relative standard deviation value. Nonetheless, the upper beach was always the most variable section for all groups.

In the study area, wave height was found to be bigger in winter (from June to September) on both years evaluated. The median of the highest quartile is a good representation of the most energetic waves (Figure 8a). In all groups, beach volume variations are related to the incident wave energy, showing the lowest volume right after the most energetic wave periods (Figure $8 \mathrm{~b}-\mathrm{d}$ ). That results in wider beaches during the summer and narrower ones during the winter.

The highest wave energy conditions observed during the period of study occurred in July 2015 (Figure 8a). This event caused a loss of 54\% (from 46 to $21 \mathrm{~m}^{3}$ ) in beach volume in Group 1 and a loss of $11 \%$ (from 39 to $34 \mathrm{~m}^{3}$ ) in Group 6. Such a difference in beach variability highlights the coastal protection ecosystem service provided by the reef. The results also showed that the exposed beach lost sediment for a few days after the storm, while the reef-protected beaches continued to gradually lose sediment a month after the storm (Table 3 ).

\section{DISCUSSION}

The wave energy reaching the coast without the nearshore reef is approximately $50 \%$ higher than the energy that reaches the reefprotected beach face. The transmission of wave energy from the reef to the shoreline is also tidally modulated, with greater wave energy reaching the shoreline at high tide. This trend has been identified in several studies on intertidal reef flats (Beetham and Kench, 2014).

At Pontal do Cupe, where the upper part of the reef emerges during low tide, the amount of wave energy in their lee is reduced. At high tide, the reef flat submerges, which reduces wave dissipation, as also observed for other beaches on Pernambuco's coast (Martins et al., 2017).

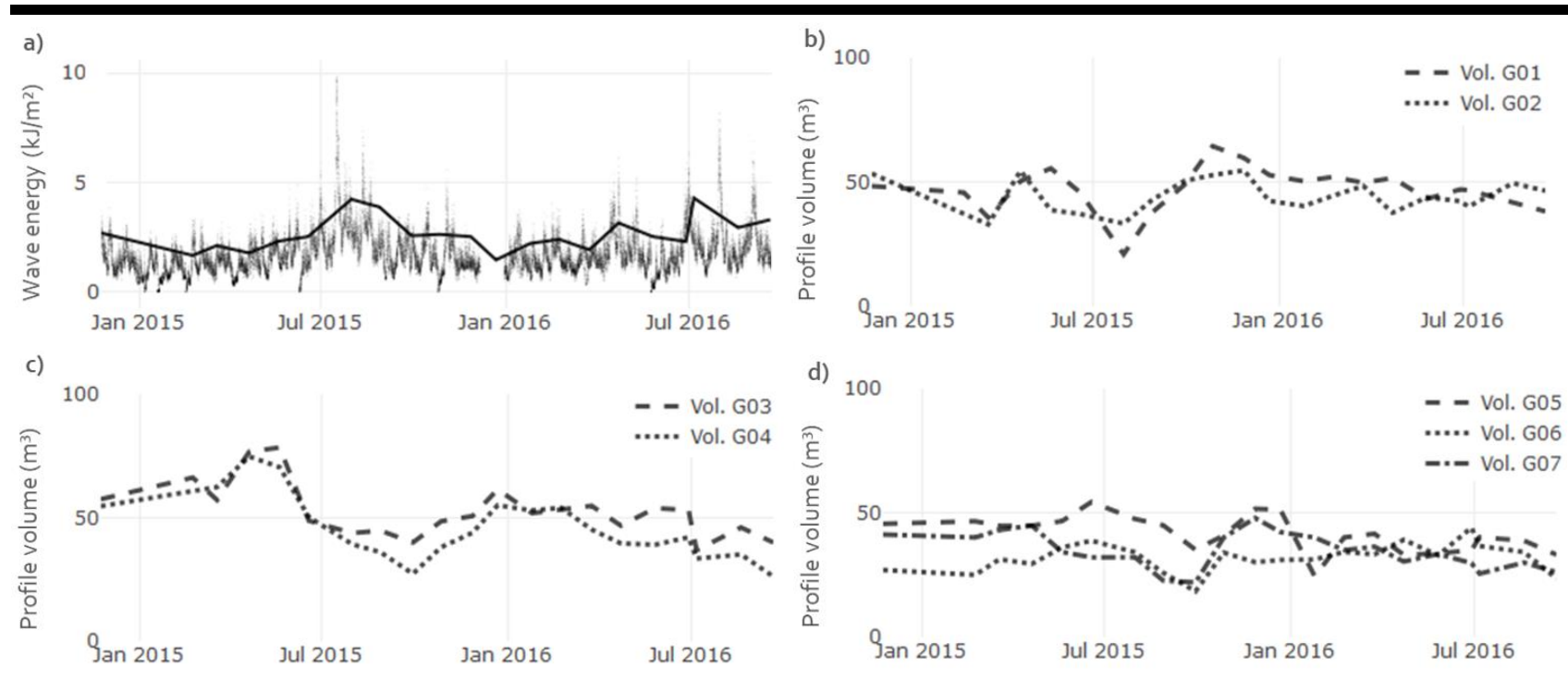

Figure 8. (a) Wave energy scatterplot chart from WWIII full data (points) and highest quartile median offshore wave energy (line); (b) Mean profile volume above MLWL for profile groups 1 and 2; (c) Mean profile volume above MLWL for profile groups 3 and 4; (d) Mean profile volume above MLWL for profile groups 5, 6 and 7 . 
The principal components that explain profile variance and justify the groups established are related to hydrodynamical processes. For most of the profiles, the $0-10 \mathrm{~m}$ chainage (first PC) is above the MHWL, which is mainly influenced by grain size and the highest waves run up. At chainages around $15 \mathrm{~m}$ (second PC), there is sediment transport between the tidal and backshore region. This highlights the influence of wave process on sediment transport between the backshore and dune region (Joevivek et al., 2017). The30-70m chainage (third PC) comprises the nearshore zone, in which wave action yields breaking waves, longshore current, and littoral transport (Short, 2012).

Following the conceptual model of beach morphodynamic stages influenced by tides (Masselink and Short, 1993), Pontal do Cupe beach could be classified as reflective during high tide and low tide terrace during low tide, except for the profiles at the reef shadow zone, which could be classified as dissipative during high tide.

Wave transformations on the reef are responsible for a salience on the coast. At this salience, beach profiles are longer and present fewer features than those on the exposed beach. The upper beach compartment was the most variable one for all profile groups. In most of the data evaluated, sediment exchange happened within the compartments. The cyclic pattern observed at Pontal do Cupe corroborates the assumption that the beach is in dynamic equilibrium, but a longer data set would be required to confirm this.

The upper beach profiles are backed by urban walls, dunes or trees, like coconut trees. In this section, sediment volume was bigger in wave-exposed profiles. In turn, sediment volume for intermediate and the lower beach was bigger on beaches modified by the tide (reef-fronted beach) than in those dominated by waves (exposed beach).

Wave energy has a faster effect on exposed profiles (groups 1, 2,3 and 4) and a lagged effect on protected profiles (5,6 and 7) (Figure 8). According to the relative standard variation of profile volumes, the reef-protected groups 5 and 6 proved to be more stable, with less variability through time, than the wave-exposed groups. Another study in a Mexican beach fronted by a fringed reef obtained similar results, with reef-fronted beaches having less sediment exchange than exposed beaches submitted to the same wave conditions (Ruiz de Alegria-Arzaburu et al. 2013). As observed by Vousdoukas, Velegrakis, and Plomaritis (2007), submerged structures like coral reefs may act as profile controls, considerably affecting the free fluctuation of beach profiles and diminishing their ability to change in response to wave energy reaching the coast.

The X-Beach 1-D result showed a reduction in the wave energy reaching the reef-fronted coast as compared to the exposed profile. Nevertheless, the reef-fronted beaches are less accessible to the sediment transported offshore during storms. This could explain the observed time lag for beach recovery after the energetic events evaluated. An example of this situation was presented in Table 3, which describes the sediment volume through time after the most energetic event occurred during the period of study. A similar conclusion was found in a study relating reefs with spatial and temporal variability of coastal erosion. It observed that reefs protected the coast from waves but did not necessarily prevent erosion (Gallop et al., 2013).

This study evaluated cross-shore sediment exchange moving from the upper beach compartment to the lower beach. Nonetheless, it is possible to infer that sediment exchange along the coast happens in two cells: one in the north, comprising the exposed profiles, and another cell at the reef-fronted beach. Still, further analysis is required to fully understand sediment transport in the area.

\section{CONCLUSIONS}

Reefs can have a significant effect on nearshore wave climate and the adjacent beach morphology. At Pontal do Cupe, the wave energy that reaches the unprotected coast is approximately $50 \%$ higher than the energy reaching the beach protected by the nearshore reef. As in other reef-fronted beaches, Pontal do Cupe beach presents less three-dimensional features than adjacent areas exposed to waves. That leads to the conclusion that the waveexposed beaches are reflective during high tide and have low tide terrace at low tide, while the reef-fronted beaches are dissipative during high tide.

The temporal variability of beach volume proved that the reeffronted beaches have less net sediment exchange than the exposed beaches, showing that the reef protects the beach from erosional processes under energetic hydrodynamics. Therefore, it is important to monitor the effects of reef degradation and climate change on wave attenuation.

Knowledge about the morphology of beach profiles on the lee side of reefs may help to improve conceptual beach models that predict change as a function of wave, tide, and sediment parameters. A better understanding of the effects of reefs can be useful to inform policymaking and beach management related to tourism and coastal protection ecosystem services. Further studies on the temporal evolution of beach profiles could provide a better understanding of reef influence on coastal morphology.

\section{ACKNOWLEDGEMENTS}

The authors are grateful to the Centro Mexicano de Innovación en Energía del Océano (CEMIE-Océano) and the German Academic Exchange Service (DAAD), Excellence Center for Development Cooperation, Sustainable Water Management (EXCEED/SWINDON) for their financial and technical support, enabling participation at the Summer School on Integrating Ecosystems in Coastal Engineering Practice (INECEP).

The author, K.A. Martins, would also like to thank the Brazilian National Council for Scientific and Technological Development - CNPq and Coordination of Improvement of Higher-Level Personnel - CAPES for granting her Doctorate scholarship.

\section{LITERATURE CITED}

Abdi, H. and Williams, L.J., 2010. Principal component analysis. Wiley Interdisciplinary Reviews: Computational Statistics, 2(4), 433-459.

Albert, J.A.; Olds, A.D.; Albert, S.; Cruz-Trinidad, A., and Schwarz, A.M., 2015. Reaping the reef: Provisioning services from coral reefs in Solomon Islands. Marine Policy, 


\section{$62,244-251$}

Alegria-Arzaburu, A.R.; Mariño-Tapia, I.; Enriquez, C.; Silva, R., and González-Leija, M., 2013. The role of fringing coral reefs on beach morphodynamics. Geomorphology, 198, 6983.

Araujo, M.; Limongi, C.; Servain, J.; Silva, M.; Leite, F.S.; Veleda, D., and Lentini, C.A.D., 2011. Salinity-induced mixed and barrier layers in the southwestern tropical Atlantic Ocean off the northeast of Brazil. Ocean Science, 7(1), 117-136.

Barbier, E.B.; Hacker, S.D.; Kennedy, C.; Kock, E.W.; Stier, A.C., and Silliman, B.R., 2011. The value of estuarine and coastal ecosystem services. Ecological Monographs, 81(2), 169-193.

Beck, M.W.; Losada, I.J.; Menéndez, P.; Reguero, B.G.; DíazSimal, P., and Fernández, F., 2018. The global flood protection savings provided by coral reefs. Nature Communications, 9(1), 2186

Beetham, E.P. and Kench, P.S., 2014. Wave energy gradients and shoreline change on Vabbinfaru platform, Maldives. Geomorphology, 209, 98-110.

Cooper, N.J.; Leggett, D.J., and Lowe, J.P., 2000. Beach-profile measurement, theory and analysis: Practical guidance and applied case studies. Journal of the Chartered Institution of Water and Environmental Management, 14(2), 79-88.

Costa, M.B.S.F.; Araújo, M.; Araújo, T.C.M., and Siegle, E., 2016. Influence of reef geometry on wave attenuation on a Brazilian coral reef. Geomorphology, 253, 318-327.

Dominguez, J.M.L.; Bittencourt, A.; Leão, Z., and Azevedo, A., 1990. Geologia Do Quaternário Costeiro Do Estado De Pernambuco. Revista Brasileira de Geociências, 20, 208215.

Ferrario, F.; Beck, M.W.; Storlazzi, C.D.; Micheli, F.; Shepard, C.C., and Airoldi, L., 2014. The effectiveness of coral reefs for coastal hazard risk reduction and adaptation. Nature Communications, 5, 3794.

Ferreira, B.P. and Maida, M., 2006. Monitoramento dos Recifes de Coral do Brasil: situação e perspectivas. Monitoramento dos recifes de coral do Brasil. Recife, Pernambuco: Ministério do Meio Ambiente - MMA Press, 116p.

Gallop, S.L.; Bosserelle, C.; Eliot, I., and Pattiaratchi, C.B., 2013. The influence of coastal reefs on spatial variability in seasonal sand fluxes. Marine Geology, 344, 132-143.

Gallop, S.L.; Bosserelle, C.; Pattiaratchi, C., and Eliot, I., 2011. Rock topography causes spatial variation in the wave, current and beach response to sea breeze activity. Marine Geology, 290(1-4), 29-40.

Joevivek, V.; Chandrasekar, N.; Saravanan, S.; Anandakumar, H.; Thanushkodi, K.; Suguna, N., and Jaya, J., 2017. Spatial and temporal correlation between beach and wave processes: implications for bar-berm sediment transition. Frontiers of Earth Science, 12(2), 349-360.

Lemke, L. and Miller, J.K., 2017. EOF analysis of shoreline and beach slope variability at a feeder beach constructed within a groin field at Long Branch, New Jersey. Coastal Engineering, 121, 14-25.

Mallmann, D.; Pereira, P.; Santos, F., and Facanha, P., 2014.
Classificação morfodinâmica das praias arenosas de Ipojuca (Pernambuco, Brasil) através da análise semântica de imagens de satélite pancromáticas. Pesquisas em Geociências, 41(2), 169-190.

Martins, K.A.; Pereira, P.S.; Silva, R., and Nogueira-Neto, A.V., 2017. The influence of climate change on coastal erosion vulnerability in Northeast Brazil. Coastal Engineering Journal, 59(2), 1-25.

Masselink, G. and Short, A.D., 1993. The effect of tide range on beach morphodynamics and morphology: A conceptual beach model. Journal of Coastal Research, 9(3), 785-800.

Mehta, V.M.; Delworth, T.; Mehta, V.M., and Delworth, T., 1995. Decadal variability of the tropical Atlantic Ocean surface temperature in shipboard measurements and in a global ocean-atmosphere model. Journal of Climate, 8(2), 172-190.

Moberg, F. and Folke, C., 1999. Ecological goods and services of coral reef ecosystems. Ecological Economics, 29(2), 215233

Pereira, P.S.; Araujo, T.C., and Vaz Manso, V.A., 2016. Tropical sandy beaches of Pernambuco State. In: Finkl, C.W. (ed.), Brazilian Beach Systems. Florida, USA: Springer, pp. 251279.

Pereira, P.S.; Martins, K.A.; Neto, A.V.; Lino, A.P.; Macaíba, M.B.; Olinto, A.; Fisher, A., and Araújo, T.C.M., 2015. Atlas de Vulnerabilidade à Erosão Costeira e Mudanças Climáticas em Pernambuco. Recife, Pernambuco: Editora Universitária (UFPE), 98p.

Rascle, N. and Ardhuin, F., 2013. A global wave parameter database for geophysical applications. Part 2: Model validation with improved source term parameterization. Ocean Modelling, 70, 174-188.

Roelvink, D.; Reniers, A.; van Dongeren, A.; van Thiel de Vries, J.; Lescinski, J., and McCall, R., 2010. XBeach model Description and Manual. UNESCO-IHE, Institute for Water Education Press, 106p.

Short, A.D., 2006. Australian beach systems - Nature and distribution. Journal of Coastal Research, 22(1), 11-27.

Short, A.D., 2012. Coastal processes and beaches. Nature Education Knowledge, 3(10), p. 15.

Short, A.D. and Trembanis, A.C., 2004. Decadal scale patterns in beach oscillation and rotation Narrabeen Beach, Australiatime Series, PCA and wavelet analysis. Journal of Coastal Research, 20(2), 523-532.

Tolman, H.L., 2009. User Manual and System Documentation of WAVEWATCH-IIITM version 3.14. NOAA/ NWS/ NCEP/ $M M A B$ : Technical Note, 276p.

USACE, 2008. Part II: Chapter 1 - Water wave mechanics. In: Mirbilek, Z. (ed.), Coastal engineering Manual, Part II, Coastal Hydrodynamics. Washington, DC., 172p.

Van Zanten, B.T.; Van Beukering, P.J.H., and Wagtendonk, A.J., 2014. Coastal protection by coral reefs: A framework for spatial assessment and economic valuation. Ocean and Coastal Management, 96, 94-103.

Vousdoukas, M.I.; Velegrakis, A.F., and Plomaritis, T.A., 2007. Beachrock occurrence, characteristics formation mechanisms and impacts. Earth-Science Reviews, 85, 23-46. 